Central Washington University

ScholarWorks@CWU

All Faculty Scholarship for the College of the Sciences

College of the Sciences

$12-30-2011$

\title{
Topographic control of asynchronous glacial advances: A case study from Annapurna, Nepal
}

\author{
Beth Pratt-Sitaula \\ Central Washington University, psitaula@geology.cwu.edu \\ Douglas W. Burbank \\ University of California, Santa Barbara \\ Arjun M. Heimsath \\ Arizona State University \\ Neil F. Humphrey \\ University of Wyoming \\ Michael Oskin \\ University of California, Davis
}

See next page for additional authors

Follow this and additional works at: https://digitalcommons.cwu.edu/cotsfac

Part of the Climate Commons, Geology Commons, and the Glaciology Commons

\section{Recommended Citation \\ Pratt-Sitaula, B., D. W. Burbank, A. M. Heimsath, N. F. Humphrey, M. Oskin, and J. Putkonen (2011), Topographic control of asynchronous glacial advances: A case study from Annapurna, Nepal, Geophys. Res. Lett., 38, L24502, doi:10.1029/2011GL049940.}

This Article is brought to you for free and open access by the College of the Sciences at ScholarWorks@CWU. It has been accepted for inclusion in All Faculty Scholarship for the College of the Sciences by an authorized administrator of ScholarWorks@CWU. For more information, please contact scholarworks@cwu.edu. 
Authors

Beth Pratt-Sitaula, Douglas W. Burbank, Arjun M. Heimsath, Neil F. Humphrey, Michael Oskin, and Jaakko Putkonen 


\title{
Topographic control of asynchronous glacial advances: A case study from Annapurna, Nepal
}

\author{
Beth Pratt-Sitaula, ${ }^{1}$ Douglas W. Burbank, ${ }^{2}$ Arjun M. Heimsath, ${ }^{3}$ Neil F. Humphrey, ${ }^{4}$ \\ Michael Oskin, ${ }^{5}$ and Jaakko Putkonen ${ }^{6}$ \\ Received 9 October 2011; revised 15 November 2011; accepted 18 November 2011; published 30 December 2011.
}

[1] Differences in the timing of glacial advances, which are commonly attributed to climatic changes, can be due to variations in valley topography. Cosmogenic ${ }^{10} \mathrm{Be}$ dates from 24 glacial moraine boulders in 5 valleys define two age populations, late-glacial and early Holocene. Moraine ages correlate with paleoglacier valley hypsometries. Moraines in valleys with lower maximum altitudes date to the lateglacial, whereas those in valleys with higher maximum altitudes are early Holocene. Two valleys with similar equilibrium-line altitudes (ELAs), but contrasting ages, are $<5 \mathrm{~km}$ apart and share the same aspect, such that spatial differences in climate can be excluded. A glacial mass-balance cellular automata model of these two neighboring valleys predicts that change from a cooler-drier to warmer-wetter climate (as at the Holocene onset) would lead to the glacier in the higher altitude catchment advancing, while the lower one retreats or disappears, even though the ELA only shifted by $\sim 120 \mathrm{~m}$. Citation: Pratt-Sitaula, B., D. W. Burbank, A. M. Heimsath, N. F. Humphrey, M. Oskin, and J. Putkonen (2011), Topographic control of asynchronous glacial advances: A case study from Annapurna, Nepal, Geophys. Res. Lett., 38, L24502, doi:10.1029/2011GL049940.

\section{Introduction}

[2] Glaciers are potentially valuable recorders of terrestrial climate change - delicately tuned to the combined effect of snow fall and temperature. The complex reality of glacial behavior, however, can hinder efforts to create reliable climatic reconstructions. Although regional climatic signals are commonly discernible, individual glaciers have been shown to advance and retreat asynchronously at local, regional, and global scales [e.g., Benn and Owen, 1998; Gillespie and Molnar, 1995]. Further understanding of the factors that lead to disparate glacial behavior will improve interpretation of past climate and prediction of future glacial change. Previous researchers have suggested that hypsometry plays a

\footnotetext{
${ }^{1}$ Geological Sciences Department, Central Washington University, Ellensburg, Washington, USA.

${ }^{2}$ Department of Earth Science, University of California, Santa Barbara, California, USA.

${ }^{3}$ School of Earth and Space Exploration, Arizona State University, Tempe, Arizona, USA.

${ }^{4}$ Department of Geology and Geophysics, University of Wyoming, Laramie, Wyoming, USA.

${ }^{5}$ Geology Department, University of California, Davis, California, USA.

${ }^{6}$ Department of Geology and Geological Engineering, University of North Dakota, Grand Forks, North Dakota, USA.
}

Copyright 2011 by the American Geophysical Union. 0094-8276/11/2011GL049940 role in glacial asynchrony [e.g., Chenet et al., 2010; Kerr, 1993], but this study is the first to test the hypothesis rigorously with a combination of modeling and field work. Results from this study quantify, more thoroughly than in previous studies, how glacial hypsometry, as well as climate, can drive asynchronous glacial behavior.

\section{Background and Methods}

[3] Prior studies of glaciation in the Annapurna area are limited to broad regional surveys [e.g., Fort and Derbyshire, 1988; Hagen, 1968; Owen et al., 1998], recent glacial erosion estimates [Heimsath and McGlynn, 2008], and limited, scattered ${ }^{10} \mathrm{Be}$ dating [Zech et al., 2009]. Further east in Nepal, other glacial dating studies [Finkel et al., 2003; Gayer et al., 2006; Owen et al., 2009] have found ice extent maxima at times broadly consistent with those presented here. This study in the Annapurna region of central Nepal (Figure 1) combines field observations, ${ }^{10} \mathrm{Be}$ dating of glacial boulders, digital elevation model (DEM) analysis, and cellular automata modeling of glacial mass balance to test the hypothesis that identical climate change can cause coeval advance and retreat of neighboring glaciers in drainage basins that have significantly different hypsometries.

\subsection{Cosmogenic ${ }^{10} \mathrm{Be}$ Dating}

[4] We dated moraines in valleys spanning a range of locations and altitudinal extents. Two valleys lie north (leeward) of the Annapurna Range (Figure 1b); one is on the range crest (Figure 1c); and two lie to the south (windward) (Figure 1d). Syaktan valley (Figure 1b) and Danfe valley (Figure 1d) descend from peaks $\geq 5500 \mathrm{~m}$, whereas ridgelines in the other 3 valleys are $<5200 \mathrm{~m}$ high. The dated glacial valleys are small $\left(<8 \mathrm{~km}^{2}\right)$ and not complicated by significant avalanching which can displace snow far below the climatic equilibrium [Harper and Humphrey, 2003]. Valley bottoms are free of obvious hummocky morphology and lack large headwalls, suggesting that the glacier surfaces were free of extensive debris cover. Each valley has only one major set of preserved moraines and no modern glaciers. The moraines have multiple crests in places, but soil development and morphology do not change significantly from one crest to the next, thereby suggesting deposition over a short interval. Of particular note, the two northern valleys (Figure 1b) lie $<5 \mathrm{~km}$ apart and have the same aspect and climate. Four to seven moraine-crest boulders were sampled from each valley (Figure 1 and Table S1 in the auxiliary material). ${ }^{1}$ We prepared samples using standard procedures

\footnotetext{
${ }^{1}$ Auxiliary materials are available in the HTML. doi:10.1029/ 2011 GL049940.
} 

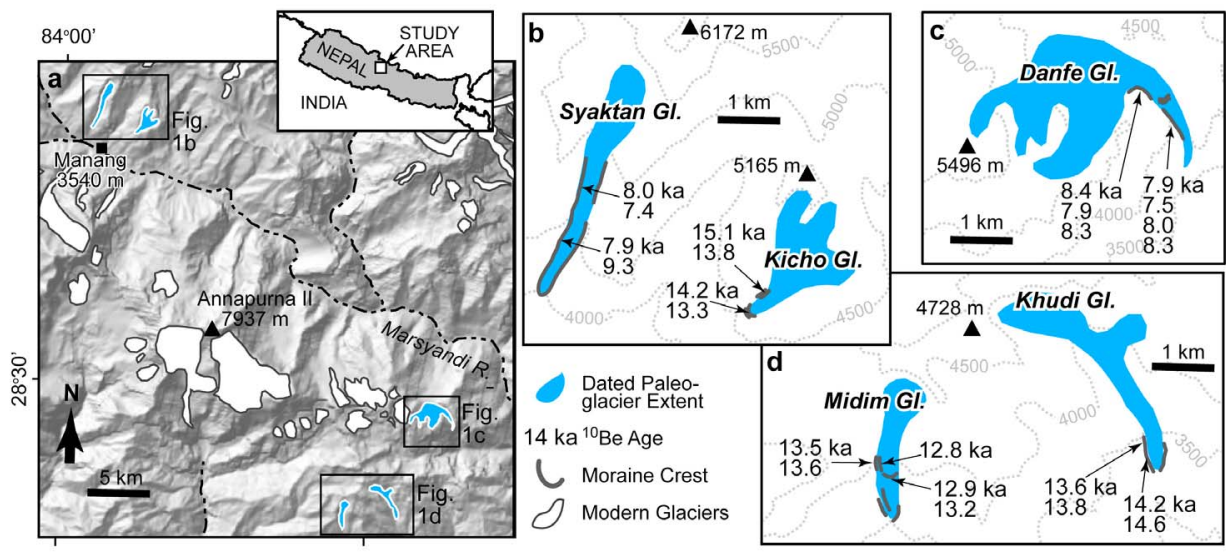

Figure 1. a) Shaded relief map of the field area with locations of detailed maps. Main Marsyandi valley contains numerous degraded, pre-Holocene glacial and landslide deposits more fully described in regional surveys [Fort and Derbyshire, 1988; Hagen, 1968; Owen et al., 1998]. b-d) Detailed maps of sample locations, ${ }^{10} \mathrm{Be}$ exposure ages, moraine crests, and paleoglacier extents.

[e.g., Kohl and Nishiizumi, 1992] and measured the ${ }^{10} \mathrm{Be}$ concentrations at Lawrence Livermore National Laboratory. Ages were calculated using v2.2 CRONUS-Earth online calculator [Balco et al., 2008]. Ages presented in this paper are from the Lal [1991] and Stone [2000] time-dependent scaling model. Results from other scaling models (Table S2) nearly all fall within the external error bars of the timedependent Lal/Stone model (Figure 2a), thus differences in scaling models, although important to consider, do not affect the conclusions of the study.

\subsection{Topographic Analysis: Glacial Hypsometry and Equilibrium Line Altitudes}

[5] Based on valley morphology and moraine location determined from air photo and field analysis, we digitized areas for each paleoglacier onto georeferenced topographic maps [Finnish Meteorological Institute, 2001], and glacierbed hypsometry was calculated from a 3-arcsecond ( $\sim 90-\mathrm{m})$ Shuttle Radar Topography Mission data (Figure 3). For each paleoglacier, the former ELA (equilibrium-line altitude where net snow mass input is balanced by the local net snow melt) was estimated using the calculated hypsometries and assuming an accumulation-area ratio of 0.60 . Work in Nepal [Ageta and Higuchi, 1984; Benn and Lehmkuhl, 2000] and elsewhere [e.g., Benn et al., 2005; Porter, 2000] shows that the accumulation zone typically occupies $50-80 \%$ of a glacier's area. Because use of other accumulation-area ratios [e.g., Kern and Laszlo, 2010] or other methods (e.g., area-altitude balance ratio [Benn et al., 2005; Rea, 2009]) changes the absolute ELA estimates somewhat, but does not alter our primary conclusions, we used a method and ratio in common use for inter-study comparability.

\subsection{Glacial Mass Balance Model}

[6] A cellular automata model [Harper and Humphrey, 2003] was used to investigate how changes in glacial ELA and mass balance influence glacial dynamics. The model requires an input ELA, a mass-balance curve (change in mass gain or loss versus altitude), and topography of the entire glacial valley. From these, the net mass of snow input is calculated for each altitude. At each time-step, the ice is

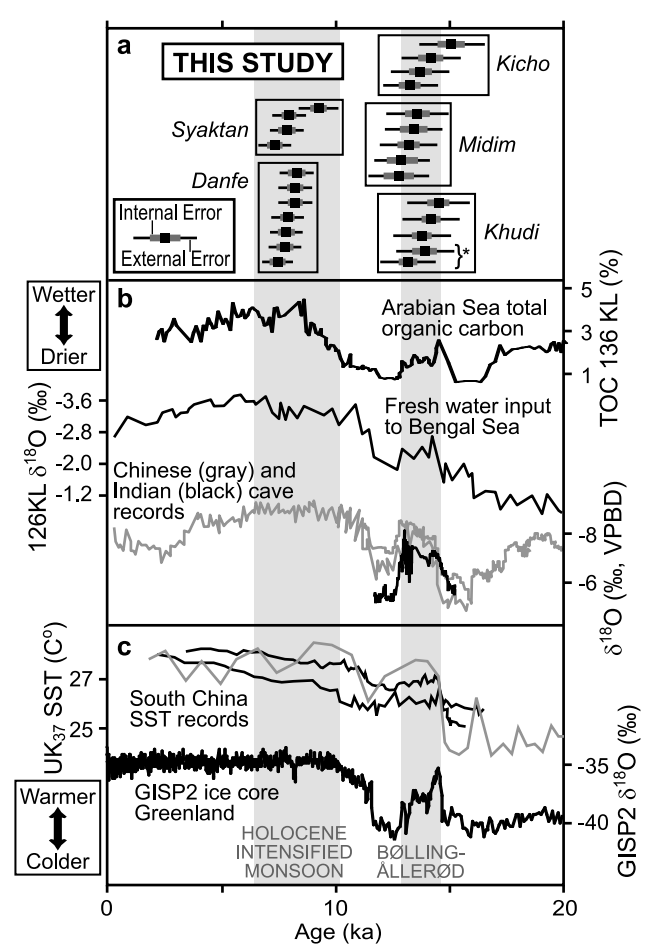

Figure 2. Glacial chronologies and paleoclimate proxies. Vertical gray bands indicate the temporal extent of the Holocene intensified monsoon and the Bølling-Ållerød. a) Moraine boulder ${ }^{10} \mathrm{Be}$ exposure ages from this study. Names and boxes refer to individual valleys (see Figure 1). The gray error bar shows the internal error from laboratory, AMS, and snowshielding uncertainties. The thin black error bar shows the external error from the production rate scaling model. *Indicates single sample that was split for analysis and provides a measure of laboratory repeatability. b) Paleoprecipitation proxies: Arabian Sea total organic carbon [Schulz et al., 1998], Bengal Sea freshwater [Kudrass et al., 2001], Hulu [Wang et al., 2001] and Dongge [Yuan et al., 2004] cave records in gray, Tinta cave record [Sinha et al., 2005] in black. c) Paleotemperature proxies: South China Sea surface temperatures (SST) in black [Kienast et al., 2001] and gray [Oppo and Sun, 2005] and GISP2 ice core record [Alley et al., 1995]. 

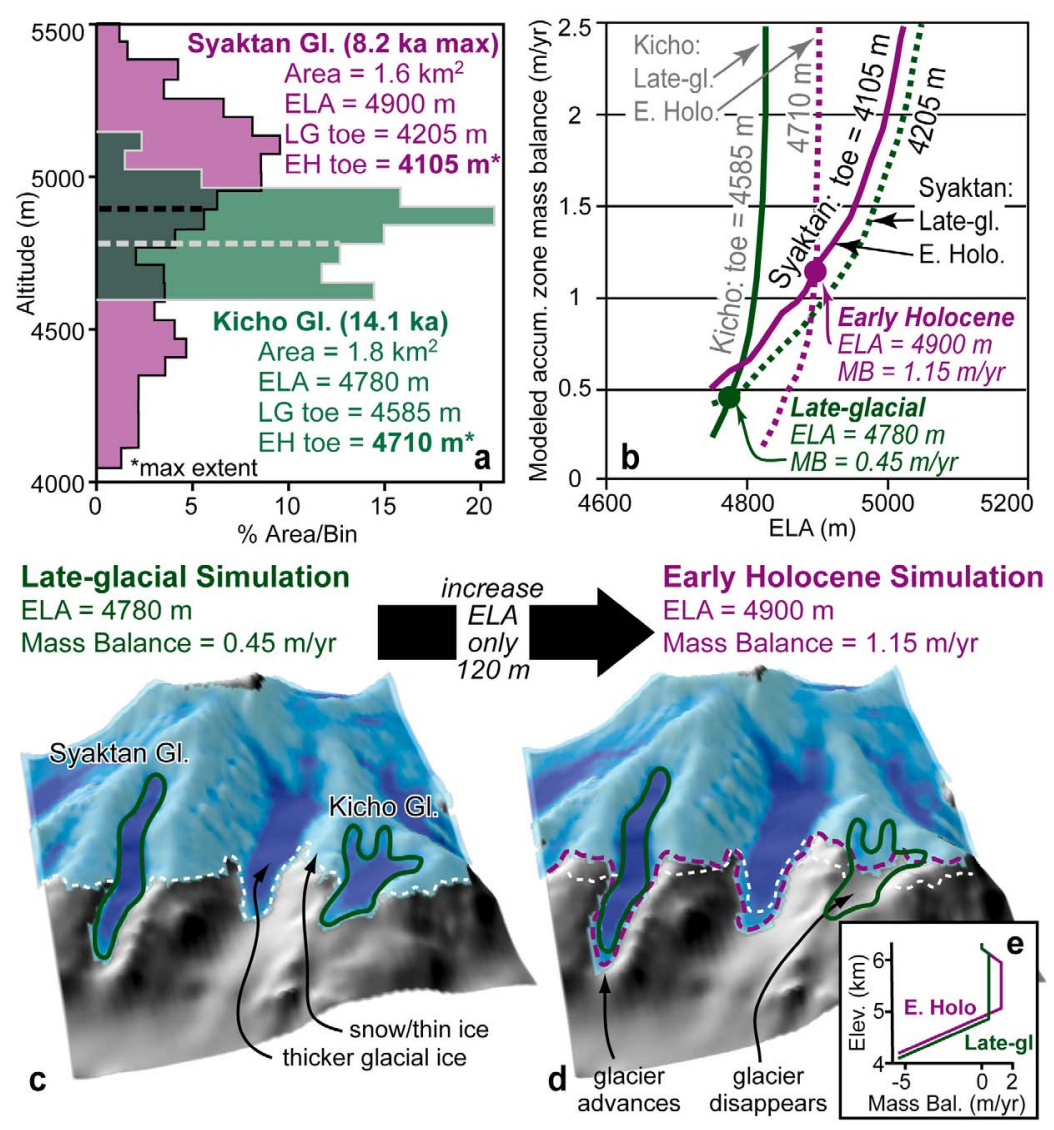

Figure 3. Topographic analysis and cellular automata model results. a) ELAs and glacial bed hypsometries of the paleoglaciers in Syaktan and Kicho valleys, early Holocene (EH) and late-glacial (LG) chronozone, respectively). b) Modelderived relationship between ELA and accumulation-zone mass balance (AZMB). Green indicates late-glacial model, and purple is early Holocene. Solid lines show relationship when modeled glaciers are at their mapped toe elevations. At the topographically estimated ELA of $4780 \mathrm{~m}$ for the maximum Kicho glacier, the model predicts Kicho's AZMB $=0.45 \mathrm{~m} / \mathrm{yr}$. This AZMB places Syaktan's toe at $4205 \mathrm{~m}$ (dashed green line), $100 \mathrm{~m}$ higher than its observed maximum extent. Similarly, at ELA= $4900 \mathrm{~m}$, Syaktan reaches full extent when the AZMB $=1.15 \mathrm{~m} / \mathrm{yr}$, but Kicho's toe elevation rises to $4710 \mathrm{~m}$ (dashed purple line), which is so high the glacier probably does not exist anymore. c) Late-glacial simulation: both valleys are predicted to have had robust glaciers. d) Early Holocene simulation: raising the ELA just $120 \mathrm{~m}$ causes the Kicho Gl. to recede significantly, whereas the Syaktan Gl. advances if the mass balance is increased. e) Mass balance curves used. Balance gradient in ablation zone $=$ $8 \mathrm{~m} / \mathrm{yr} / \mathrm{km}$ [Harper and Humphrey, 2003].

routed across the landscape according to two basic assumptions about ice behavior. If the surface slope is $>35^{\circ}$, it is unstable and any snow avalanches to the next lowest cell. If the ice surface is $<35^{\circ}$, the ice thickness varies in order to maintain a basal shear stress $\left(\tau_{\mathrm{b}}\right)$ of 1 bar [Nye, 1952; Paterson, 1994]. Thus,

$$
\tau_{b}=\rho g h S \approx 1 \text { bar },
$$

where $\rho=$ density, $g=$ force due to gravity, $h=$ ice thickness, and $S=$ ice surface slope. Any ice thickness causing stresses exceeding 1 bar will flow to the lowest adjacent cell. To match the values determined for modern Annapurna area glaciers [Harper and Humphrey, 2003], the upper boundary for significant snowfall was set to $6200 \mathrm{~m}$, the mass balance was set to be constant through the accumulation area until just above the ELA, where it decreases at a constant rate of $8 \mathrm{~m} / \mathrm{yr}$ per $\mathrm{km}$ of altitude through the ablation area. The bulk of the studied glacial valleys are below $6000 \mathrm{~m}$, such that model results are insensitive to the upper snow boundary. Likewise, changing the mass balance gradient in the ablation zone by $\pm 4 \mathrm{~m} / \mathrm{yr} / \mathrm{km}$ does not significantly change the outcome. Although the model does not mimic ice flow exactly, it succeeds in predicting general ice extent in modern Himalayan glaciers [Harper and Humphrey, 2003].

\section{Results and Interpretation}

[7] The ${ }^{10} \mathrm{Be}$ exposure ages were consistent within each valley (Table 1 and Figure 2a), with no outliers. The dates fall into 2 distinct populations: $15-13 \mathrm{ka}$ and $\sim 8 \mathrm{ka}$. Kicho valley ages range from 13.3 to $15.1 \mathrm{ka}$ with a sample mean of $14.1 \pm 0.8 \mathrm{ka}$, Midim valley ages are 12.8-13.6 ka with a mean of $13.3 \pm 0.3 \mathrm{ka}$, and Khudi valley ages are 13.2-14.6 ka with a mean of $14.1 \pm 0.4 \mathrm{ka}$. The younger ages come from Syaktan valley with a range of 7.4-9.3 ka with a mean of $8.2 \pm 0.8 \mathrm{ka}$ and Danfe valley where ages are 7.5-8.3 ka with a mean of $8.0 \pm 0.3 \mathrm{ka}$. We conclude that spatially 
Table 1. ${ }^{10}$ Be Moraine Boulder Exposure Ages ${ }^{\mathrm{a}}$

\begin{tabular}{lcccc}
\hline $\begin{array}{c}\text { Sample } \\
\text { Number }\end{array}$ & $\begin{array}{c}\text { Age } \\
\text { (ka) }\end{array}$ & $\begin{array}{c}\text { Internal } \\
\text { Error } \\
\text { (ka) }\end{array}$ & $\begin{array}{c}\text { External } \\
\text { Error } \\
\text { (ka) }\end{array}$ & $\begin{array}{c}\text { Site Average } \\
\text { and SD } \\
(\mathrm{ka})\end{array}$ \\
\hline CRN-222 & 14.2 & 0.5 & 1.3 & $14.1 \pm 0.8$ \\
CRN-223 & 13.3 & 0.4 & 1.2 & Kicho \\
CRN-224 & $\mathbf{1 5 . 1}$ & 0.6 & 1.4 & \\
CRN-225 & 13.8 & 0.5 & 1.2 & $8.2 \pm 0.8$ \\
CRN-226 & 7.9 & 0.3 & 0.7 & Syaktan \\
CRN-227 & $\mathbf{9 . 3}$ & 0.3 & 0.8 & \\
CRN-228 & 8.0 & 0.3 & 0.7 & $13.2 \pm 0.3$ \\
CRN-229 & 7.4 & 0.3 & 0.7 & Midim \\
CRN-246 & 13.5 & 0.5 & 1.2 & \\
CRN-247 & $\mathbf{1 3 . 6}$ & 0.5 & 1.3 & Khudi \\
CRN-248 & 12.8 & 0.6 & 1.3 & \\
CRN-249 & 12.9 & 0.7 & 1.2 & \\
CRN-250 & 13.2 & 0.5 & 1.2 & \\
CRN-251 & 14.2 & 0.4 & 1.3 & 1.3 \\
CRN-252 & $\mathbf{1 4 . 6}$ & 0.4 & 1.3 & \\
CRN-253a & 13.9 & 0.5 & 1.3 & Danfe \\
CRN-253b & 13.2 & 0.4 & 1.2 & \\
CRN-254 & 13.8 & 0.4 & 1.2 & \\
CRN-433 & 7.9 & 0.3 & 0.7 & \\
CRN-434 & 7.5 & 0.2 & 0.7 & \\
CRN-435 & 8.0 & 0.3 & 0.7 & \\
CRN-437 & 8.3 & 0.3 & 0.7 & \\
CRN-438 & $\mathbf{8 . 4}$ & 0.3 & 0.7 & \\
CRN-439 & 7.9 & 0.3 & 0.7 & \\
CRN-440 & 8.3 & 0.3 & 0.7 & \\
\hline
\end{tabular}

\footnotetext{
${ }^{\mathrm{a}}$ Ages were calculated using the CRONUS-Earth online calculator V2.2 with the time-integrated $\mathrm{Lal} / \mathrm{Stone}$ production rate scaling model. Site maximums are in bold. Errors are $1 \sigma$. Internal errors include carrier density, AMS, and snow shielding uncertainties. External errors reflect scaling model/nuclide production rate uncertainties. Corrections were made for atmospheric thickness, geomagnetic position, topographic shielding, sample thickness, and snow cover. CRN-253 was split for analysis; the two resulting ages were averaged before the site average was calculated. See Table S1 and auxiliary material for additional information.
}

variable climate cannot account for the asynchrony, because glaciers to both the north (Figure 1b) and the southeast (Figures 1c and 1d) fall in both age populations. The northern glaciers are particularly notable, because they lie so close together $(<5 \mathrm{~km}$ apart $)$ and share the same aspect; yet, the last advance of each occurred at strikingly different times.
[8] The more recent glacial advances $(\sim 8 \mathrm{ka})$ fall in the middle of the early Holocene intensified summer monsoon from $\sim 10.5$ to $6.5 \mathrm{ka}$ [e.g., Burns et al., 2001; Gasse et al., 1991; Yuan et al., 2004], whereas the earlier advance falls during the late-glacial period. The late-glacial advance may be associated with the Bølling-Ållerød (Greenland Interstadial 1 [Johnsen et al., 1992]) which spanned 14.6-12.9 ka but current ${ }^{10} \mathrm{Be}$ dating resolution does not allow this correlation to be made definitively [e.g., Balco, 2011]. Whether one uses site-averaged or oldest-age as the best minimum date for ice retreat [e.g., Chevalier et al., 2011; Heyman et al., 2011; Putkonen et al., 2008], the two observed age populations (early Holocene and late-glacial) are consistent with other dates for Himalayan glacial sites [Owen, 2009] and are statistically robust. Paleoprecipitation records of the Indian [Kudrass et al., 2001; Schulz et al., 1998; Sinha et al., 2005] and Asian monsoons [Wang et al., 2001; Yuan et al., 2004] demonstrate that the early Holocene was wetter than the late-glacial period, even during the Bølling-Ållerød (Figure 2b). Himalayan paleotemperature records are limited, but records from elsewhere in Asia and globally [e.g., Alley et al., 1995; Kienast et al., 2001; Oppo and Sun, 2005] demonstrate that the early Holocene was warmer (Figure 2c).

[9] Moraine ages vary systematically with the altitude range of reconstructed glaciers. Glaciers during the lateglacial (Kicho, Midim, and Khudi) lay mostly or entirely below $5000 \mathrm{~m}$, whereas the early Holocene glaciers (Syaktan and Danfe) had significant area above $5000 \mathrm{~m}$. Hereafter, we focus primarily on the northern glaciers (Kicho and Syaktan) because their proximity to each other and identical orientation rule out local climatic differences as a cause of their asynchronous advances. Kicho Glacier (14.1 ka) had a very narrow altitude range with $<5 \%$ above $5000 \mathrm{~m}$, whereas the Syaktan Glacier (8.2 ka) ranged $4100-5400 \mathrm{~m}$, with $>40 \%$ above $5000 \mathrm{~m}$ and ridgelines as high as $6170 \mathrm{~m}$ (Figure 3a). Despite the differences in moraine ages and hypsometry, reconstructed ELAs for the two paleoglaciers are remarkably similar with Kicho (14.1 ka) at $4780 \mathrm{~m}$ and Syaktan $(8.2 \mathrm{ka})$ at $4900 \mathrm{~m}$.

[10] We hypothesize that a climate change causing only a modest change in ELA, say $120 \mathrm{~m}$, could cause dissimilar responses in glaciers of contrasting hypsometries.
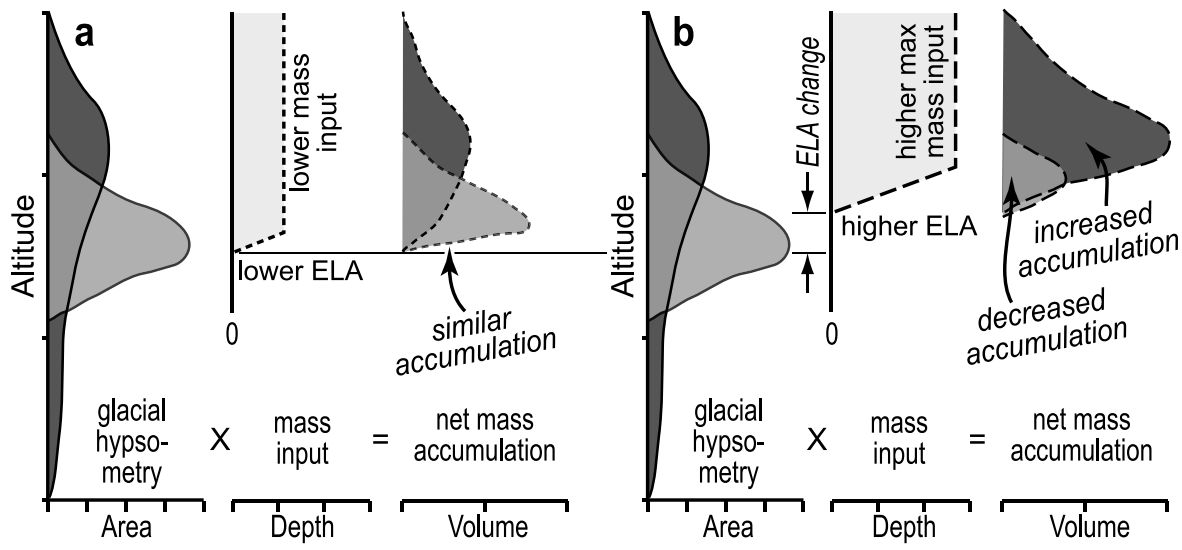

Figure 4. Schematic diagram of net mass accumulation for two equal-sized glaciers with different bed hypsometries under two different climate scenarios. a) Net accumulations are sub-equal when ELA and mass input are lower (cooler, drier); b) When ELA and mass input are raised (warmer, wetter), net accumulation increases for the higher altitude glacier, but decreases for the lower glacier. 
In particular, warmer but wetter conditions could cause glaciers with higher-altitude source areas to advance as lower-altitude glaciers recede. To test this hypothesis, we used the cellular automata model to explore relationships among ELA, mass balance in the accumulation area, and position of the glacial toe. Consistent with our observations, we assume no significant debris cover: a key factor given the potential for such cover to strongly influence glacial behavior [Scherler et al., 2010]. We simulated "late-glacial" conditions with an ELA of $4780 \mathrm{~m}$ and "early Holocene" conditions with an ELA of $4900 \mathrm{~m}$. In the late-glacial simulations, glaciers fill both valleys and reach a steadystate position by 300 model years (Figure 3c). With an ELA of $4780 \mathrm{~m}$ and a mass balance (water equivalent) in the accumulation zone of $0.45 \mathrm{~m} / \mathrm{yr}$, the toe of the model Kicho glacier reached the same level $(4585 \mathrm{~m})$ as the actual glacier did at its maximum (Figure $3 b$ ). Under the same conditions, the model predicts that the Syaktan glacier toe remains some $100 \mathrm{~m}$ above its lowest position. However, when the mass balance in the accumulation zone is increased as the ELA rises (paleoclimate indicators suggest that the Early Holocene was wetter - Figure 2), Syaktan actually advances, while Kicho glacier melts away (Figure 3d). A mass balance of $1.15 \mathrm{~m} / \mathrm{yr}$ in the accumulation zone brings the Syaktan toe to its mapped altitude (4105 m) (Figure 3b).

[11] The model is probably not so well constrained that the specific accumulation-zone mass balances $(1.15 \mathrm{~m} / \mathrm{yr}$ or $0.45 \mathrm{~m} / \mathrm{yr}$ ) are accurate, but the sense of change is significant. Thus, we interpret the results from moraine dating and computer modeling to show that a change in climate in this case from a colder, drier time when the ELA and accumulation-zone mass balance were lower to one that was warmer and wetter when the ELA and mass balance were (slightly) higher - can lead some glaciers to advance, while others retreat, due solely to differences in their hypsometries (Figure 4). The net outcome, as recorded by moraine ages that differ by $>40 \%$, is asynchronous maximum ice extent in neighboring valleys.

\section{Conclusions}

[12] The unique combination of factors - multiple, welldated paleoglaciers that have different hypsometries and fall into two distinct age populations from different climatic periods - allowed us to test the effect of hypsometry on glacial dynamics. The results quantify how topography can play a fundamental role in glacial behavior, causing some glaciers to advance while others retreat in the face of uniform climate change. The study is the first of its kind and has several significant implications. First, we provide a specific example of how hypsometry must be considered in analyses of alpine glacial dates; specifically, higher altitude sources areas will likely lead to a wider range of climate conditions conducive to glacial advance. Our results provide an explanation for some observed asynchrony by demonstrating that neighboring glaciers can have opposite responses to a uniform change in climate. Second, the commonly used technique of dating moraines in a single valley and then correlating that date to other moraines in the area that show a similar ELA depression should be conducted cautiously. Others have noted this [e.g., Benn et al., 2005], but here we provide quantitative evidence that different climate regimes can lead to nearly identical ELAs. Third, our data yield additional insights into Himalayan paleoclimate. The amassed paleoclimate data show the early Holocene was wetter than the pre-Holocene period, but few terrestrial data sources exist, particularly for paleotemperature. The lower ELA observed in the late-glacial, despite less snow, strongly suggests that this period was colder, not just drier than the early Holocene.

[13] Despite the potential of using moraines as paleoclimate indicators, the complexity of glacial behavior has long challenged researchers. In this study, we demonstrate how hypsometry influences glacial behavior. In addition we present the largest and best-constrained ${ }^{10} \mathrm{Be}$ dates available for glacial advances in the central or western Nepal Himalaya.

[14] Acknowledgments. Financial support came from the National Science Foundation Continental Dynamics program (EAR-99-09647) and the University of California Chancellor's Fellowship Program. The Nepal Department of Hydrology and Meteorology and Himalayan Experience provided excellent logistical assistance. Comments by D. Benn, B. Singer, R. Anderson, S. Brocklehurst, and anonymous were much appreciated.

[15] The Editor thanks Simon Brocklehurst and Robert Anderson for their assistance in evaluating this paper.

\section{References}

Ageta, Y., and K. Higuchi (1984), Estimation of mass balance components of a summer-accumulation type glacier in the Nepal Himalaya, Geogr. Ann., Ser. A, 66(3), 249-255, doi:10.2307/520698.

Alley, R. B., A. J. Gow, S. J. Johnsen, J. Kipfstuhl, D. A. Meese, and T. Thorsteinsson (1995), Comparison of deep ice cores, Nature, 373(6513), 393-394, doi:10.1038/373393b0.

Balco, G. (2011), Contributions and unrealized potential contributions of cosmogenic-nuclide exposure dating to glacier chronology, 1990-2010, Quat. Sci. Rev., 30, 3-27, doi:10.1016/j.quascirev.2010.11.003.

Balco, G., J. O. Stone, N. A. Lifton, and T. J. Dunai (2008), A complete and easily accessible means of calculating surface exposure ages or erosion rates from ${ }^{10} \mathrm{Be}$ and ${ }^{26} \mathrm{Al}$ measurements, Quat. Geochronol., 3(3), 174-195, doi:10.1016/j.quageo.2007.12.001.

Benn, D. I., and F. Lehmkuhl (2000), Mass balance and equilibrium-line altitudes of glaciers in high-mountain environments, Quat. Int., 65-66, 15-29, doi:10.1016/S1040-6182(99)00034-8.

Benn, D. I., and L. A. Owen (1998), The role of the Indian summer monsoon and the mid-latitude westerlies in Himalayan glaciation: Review and speculative discussion, J. Geol. Soc., 155(2), 353-363, doi:10.1144/gsjgs.155.2.0353.

Benn, D. I., L. A. Owen, H. A. Osmaston, G. O. Seltzer, S. C. Porter, and B. Mark (2005), Reconstruction of equilibrium-line altitudes for tropical and sub-tropical glaciers, Quat. Int., 138-139, 8-21, doi:10.1016/j. quaint.2005.02.003.

Burns, S. J., D. Fleitmann, A. Matter, U. Neff, and A. Mangini (2001), Speleothem evidence from Oman for continental pluvial events during interglacial periods, Geology, 29(7), 623-626, doi:10.1130/0091-7613(2001) $029<0623$ :SEFOFC $>2.0 . \mathrm{CO} ; 2$.

Chenet, M., E. Roussel, V. Jomelli, and D. Grancher (2010), Asynchronous Little Ice Age glacial maximum extent in southeast Iceland, Geomorphology, 114(3), 253-260, doi:10.1016/j.geomorph.2009.07.012.

Chevalier, M.-L., G. Hilley, P. Tapponnier, J. Van Der Woerd, J. Liu-Zeng, R. C. Finkel, F. J. Ryerson, H. Li, and X. Liu (2011), Constraints on the late Quaternary glaciations in Tibet from cosmogenic exposure ages of moraine surfaces, Quat. Sci. Rev., 30(5-6), 528-554, doi:10.1016/j. quascirev.2010.11.005.

Finkel, R. C., L. A. Owen, P. L. Barnard, and M. W. Caffee (2003), Beryllium-10 dating of Mount Everest moraines indicates a strong monsoon influence and glacial synchroneity throughout the Himalaya, Geology, 31(6), 561-564, doi:10.1130/0091-7613(2003)031<0561: BDOMEM $>2.0 . \mathrm{CO} ; 2$.

Finnish Meteorological Institute (2001), Topographic Map of Nepal, Gov. of Nepal Surv. Dep., Kathmandu.

Fort, M., and E. Derbyshire (1988), Some characteristics of tills in the Annapurna Range, Nepal, in The Paleoenvironment of East Asia From the Mid-Tertiary, edited by P. Whyt et al., pp. 195-214, Cent. of Asian Stud., Univ. of Hong Kong, Hong Kong.

Gasse, F., et al. (1991), A 13,000-year climate record from western Tibet, Nature, 353(6346), 742-745, doi:10.1038/353742a0.

Gayer, E., J. Lave, R. Pik, and C. France-Lanord (2006), Monsoonal forcing of Holocene glacier fluctuations in Ganesh Himal (central Nepal) 
constrained by cosmogenic ${ }^{3} \mathrm{He}$ exposure ages of garnets, Earth Planet. Sci. Lett., 252(3-4), 275-288, doi:10.1016/j.eps1.2006.09.040.

Gillespie, A. R., and P. Molnar (1995), Asynchronous maximum advances of mountain and continental glaciers, Rev. Geophys., 33(3), 311-364, doi:10.1029/95RG00995.

Hagen, T. (1968), Report on the Geological Survey of Nepal, vol. 2, Geology of the Thakkhola, Fretz, Zurich, Switzerland.

Harper, J. T., and N. F. Humphrey (2003), High altitude Himalayan climate inferred from glacial ice flux, Geophys. Res. Lett., 30(14), 1764 , doi:10.1029/2003GL017329.

Heimsath, A. M., and R. McGlynn (2008), Quantifying periglacial erosion in the Nepal high Himalaya, Geomorphology, 97(1-2), 5-23, doi:10.1016/j. geomorph.2007.02.046.

Heyman, J., A. P. Stroeven, J. M. Harbor, and M. W. Caffee (2011), Too young or too old: Evaluating cosmogenic exposure dating based on an analysis of compiled boulder exposure ages, Earth Planet. Sci. Lett., 302(1-2), 71-80, doi:10.1016/j.eps1.2010.11.040.

Johnsen, S. J., H. B. Clausen, W. Dansgaard, K. Fuhrer, N. Gundestrup, C. U. Hammer, P. Iversen, J. Jouzel, B. Stauffer, and J. P. Steffensen (1992), Irregular glacial interstadials recorded in a new Greenland ice core, Nature, 359(6393), 311-313, doi:10.1038/359311a0.

Kern, Z., and P. Laszlo (2010), Size specific steady-state accumulationarea ratio; an improvement for equilibrium-line estimation of small palaeoglaciers, Quat. Sci. Rev., 29(19-20), 2781-2787, doi:10.1016/j. quascirev.2010.06.033.

Kerr, A. (1993), Topography, climate and ice masses: A review, Terra Nova, 5(4), 332-342, doi:10.1111/j.1365-3121.1993.tb00266.x.

Kienast, M., S. Steinke, K. Stattegger, and S. E. Calvert (2001), Synchronous tropical South China Sea SST change and Greenland warming during deglaciation, Science, 291(5511), 2132-2134, doi:10.1126/ science. 1057131

Kohl, C. P., and K. Nishiizumi (1992), Chemical isolation of quartz for measurement of in-situ-produced cosmogenic nuclides, Geochim. Cosmochim. Acta, 56(9), 3583-3587, doi:10.1016/0016-7037(92)90401-4.

Kudrass, H. R., A. Hofmann, H. Doose, K. Emeis, and H. Erlenkeuser (2001), Modulation and amplification of climatic changes in the Northern Hemisphere by the Indian summer monsoon during the past 80 k.y. Geology, 29(1), 63-66, doi:10.1130/0091-7613(2001)029<0063:MAAOCC $>$ 2.0.CO;2.

Lal, D. (1991), Cosmic ray labeling of erosion surfaces: In situ nuclide production rates and erosion models, Earth Planet. Sci. Lett., 104(2-4), 424-439, doi:10.1016/0012-821X(91)90220-C.

Nye, J. F. (1952), A comparison between the theoretical and the measured long profile of the Unteraar glacier, J. Glaciol., 2(12), 103-107.

Oppo, D. W., and Y. Sun (2005), Amplitude and timing of sea-surface temperature change in the northern South China Sea: Dynamic link to the east Asian monsoon, Geology, 33(10), 785-788, doi:10.1130/G21867.1.

Owen, L. A. (2009), Latest Pleistocene and Holocene glacier fluctuations in the Himalaya and Tibet, Quat. Sci. Rev., 28(21-22), 2150-2164, doi:10.1016/j.quascirev.2008.10.020.

Owen, L. A., E. Derbyshire, and M. Fort (1998), The Quaternary glacial history of the Himalaya: A review, in Mountain Glaciation, edited by L. A. Owen, pp. 91-120, Quat. Res. Assoc., Cambridge, U. K.
Owen, L. A., R. Robinson, D. I. Benn, R. C. Finkel, N. K. Davis, C. L. Yi, J. Putkonen, D. W. Li, and A. S. Murray (2009), Quaternary glaciation of Mount Everest, Quat. Sci. Rev., 28(15-16), 1412-1433, doi:10.1016/j. quascirev.2009.02.010.

Paterson, W. S. B. (1994), The Physics of Glaciers, Pergamon, Oxford, U. K.

Porter, S. C. (2000), Snowline depression in the tropics during the Last Glaciation, Quat. Sci. Rev., 20(10), 1067-1091, doi:10.1016/S02773791(00)00178-5.

Putkonen, J., J. Connolly, and T. Orloff (2008), Landscape evolution degrades the geologic signature of past glaciations, Geomorphology, 97(1-2), 208-217, doi:10.1016/j.geomorph.2007.02.043.

Rea, B. R. (2009), Defining modern day Area-Altitude Balance Ratios (AABRs) and their use in glacier-climate reconstructions, Quat. Sci. Rev., 28(3-4), 237-248, doi:10.1016/j.quascirev.2008.10.011.

Scherler, D., B. Bookhagen, M. R. Strecker, F. von Blanckenburg, and D. Rood (2010), Timing and extent of late Quaternary glaciation in the western Himalaya constrained by ${ }^{10} \mathrm{Be}$ moraine dating in Garhwal, India Ouat. Sci. Rev., 29(7-8), 815-831, doi:10.1016/j.quascirev.2009.11.031.

Schulz, H., U. von Rod, and H. Erlenkeuser (1998), Correlation between Arabian Sea and Greenland climate oscillations of the past 110,000 years, Nature, 393(6680), 54-57.

Sinha, A., K. G. Cannariato, L. D. Stott, H.-C. Li, C.-F. You, H. Cheng, R. L. Edwards, and I. B. Singh (2005), Variability of southwest Indian summer monsoon precipitation during the Bølling-Ållerød, Geology, 33(10), 813-816, doi:10.1130/G21498.1.

Stone, J. O. (2000), Air pressure and cosmogenic isotope production, J. Geophys. Res., 105(B10), 23,753-23,759, doi:10.1029/2000JB900181.

Wang, Y. J., H. Cheng, R. L. Edwards, Z. S. An, J. Y. Wu, C. C. Shen, and J. A. Dorale (2001), A high-resolution absolute-dated late Pleistocene monsoon record from Hulu Cave, China, Science, 294(5550), 2345-2348, doi:10.1126/science.1064618.

Yuan, D. X., et al. (2004), Timing, duration, and transitions of the Last Interglacial Asian monsoon, Science, 304(5670), 575-578, doi:10.1126/ science. 1091220 .

Zech, R., M. Zech, P. W. Kubik, K. Kharki, and W. Zech (2009), Deglaciation and landscape history around Annapurna, Nepal, based on ${ }^{10} \mathrm{Be}$ surface exposure dating, Quat. Sci. Rev., 28(11-12), 1106-1118, doi:10.1016/j. quascirev.2008.11.013.

D. W. Burbank, Department of Earth Science, University of California, Santa Barbara, CA 93106-9630, USA.

A. M. Heimsath, School of Earth and Space Exploration, Arizona State University, Tempe, AZ 85287-1404, USA.

N. F. Humphrey, Department of Geology and Geophysics, University of Wyoming, Laramie, WY 82071-3006, USA.

M. Oskin, Geology Department, University of California, Davis, CA 95616, USA.

B. Pratt-Sitaula, Geological Sciences Department, Central Washington University, Ellensburg, WA 98926-7814, USA. (psitaula@geology.cwu. edu)

J. Putkonen, Department of Geology and Geological Engineering, University of North Dakota, Grand Forks, ND 58202-8358, USA. 